\title{
Fighting for What Matters: Care, Supporting People and Preserving a Form of Life in Baton Twirling Clubs
}

\author{
Dominique Malatesta* and Christophe Jaccoud* *
}

\begin{abstract}
In this article, we look at twirling baton clubs characterized by a specific sociality which is part of a life form. This was threatened by the demands of sportivisation from the sport institution. The protests expressed by the clubs show the attachment to a logic of care with the aim of protecting the vulnerabilities and the singular identities of the athletes who are mostly young girls.
\end{abstract}

Keywords: Care, life form, sports clubs, ethnography, inquiry

\section{Ums Entscheidende kämpfen: Care, gegenseitige Unterstützung und das Aufrecht- erhalten einer Lebensform in Baton Twirling Clubs}

Zusammenfassung: In diesem Artikel interessieren wir uns für Baton Twirling-Klubs die durch ein eigene Sozialität und Lebensform geprägt sind. Diese Lebensform ist durch von den Sportinstitutionen ausgehenden Forderungen nach einer «Versportlichung» bedroht. Der Protest der Klubs zeigt, dass diese eine Care-Logik vertreten, die zum Ziel hat, die verletzlichen Identitäten der AthletInnen (meist junge Mädchen) zu schützen.

Schlüsselwörter: Care, Lebensform, Sportklubs, Ethnographie, Untersuchung

\section{Lutter pour ce qui compte : care, ménagement des personnes et préservation d'une forme de vie dans des clubs de twirling bâton}

Résumé: Dans cet article, nous nous intéressons à des clubs de twirling bâton caractérisés par une socialité spécifique qui relève d'une forme de vie. Celle-ci a été menacée par des exigences de sportivisation issues de l'institution sportive. Les contestations manifestées par les clubs montrent l'attachement à une logique de care appelée à protéger les vulnérabilités et les identités singulières des jeunes pratiquantes.

Mots-clés: Care, forme de vie, clubs de sport, ethnographie, enquête

Faculty of Social Work, University of Applied Sciences and Arts Switzerland, (HETSL-HES-SO), CH-1010 Lausanne, dominique.malatesta@hetsl.ch

** Centre international d'étude du sport (CIES), University of Neuchâtel, CH-2000 Neuchâtel, christophe.jaccoud@unine.ch 
This contribution is dedicated to baton twirling clubs, an almost exclusively female sports discipline which stems from the practice of majorettes and shares common features with rhythmic gymnastics. There are around ten baton twirling clubs in Switzerland belonging to a federation created in 1972 . They all participate in national and international competitions, despite their small memberships and modest resources. The long-lasting existence of these clubs raises the question of overcoming their fragility as much as that of maintaining members' commitment to such a sporting activity.

The ties forged in clubs through training practices, hosting arrangements and competition objectives reveal aspirations and convictions about what a good sporting life should entail. A decision made by the Swiss Baton Twirling Federation to prepare the sport for the Olympics (which engendered modifications to the conditions of access to national competitions by reserving places for athletes who had previously passed technical events) led to the clubs articulating and claiming their sport as a "form of life" which athletes, officials and coaches have all shown they care about. In the course of this struggle for what matters above all - even more than the strict principle of athletic performance - the political dimension of these collective and ordinary commitments emerged.

In this article, we address three research questions and analytical perspectives to capture this political dimension of such commitment.

- How and under which conditions sports clubs can be places of benevolence and provide conditions which inspire lasting commitment, founded more on creating positive feelings and protecting a form of life than on the practicalities of carrying out a sporting practice.

- How sports clubs, understood conceptually as "forms of life" (Cavell 2006; Laugier 2016), i.e., as settings in which participants shape a certain idea of living together as well as life possibilities, have overcome changes - in this case, preparing their sport for the Olympics, a practice engendering a demanding production of excellence - which they considered detrimental to the vision of what an engaging sports relationship should be for children and their entourage. This process of objection took the form of an inquiry, a central concept for John Dewey, in other words, a critical observation and interpretation of the facts when confronted with an undesirable situation and a feeling of illegibility (Festenstein 2008; Putnam and Putnam 2017).

- How then did this objection develop into an object of struggle for the preservation of an activity, as well as a claim to participate and share (Fraser 1990) in its management, thus conferring a political dimension to an ordinary associative commitment? In this way, we can see how political experiences (Held 2006; Ferrarese 2018) can take place in a multitude of spheres and scenes of social life. 
The data were collected over a period of three years across 6 baton twirling clubs in French-speaking Switzerland. Three ethnographic methods specific to a comprehensive approach (Auyero and Joseph 2007) were used. ${ }^{1}$

1) an iterative in situ observation of training, competitions, travel and celebratory events; 2) an analysis of documents such as regulatory texts, press articles, archives and websites; and 3) regular collective and individual interviews with young athletes, instructors, club managers, and members of the Federation and families ${ }^{2}$.

After a presentation of baton twirling and the development of the conceptual framework based on pragmatic sociology, we will explore the event which prompted clubs to protest, to an inquiry, and will analyze the intricacies and implications of this event, invoking the theory of care and more specifically its political dimension.

\section{Baton Twirling: A Low Publicity Sport Which is High in Commitment}

Baton twirling is a discipline which combines gymnastics, dance and baton handling. The athletes perform at competition level, usually to choreographed music. It is a minority sport in Switzerland, where only around ten clubs ${ }^{3}$ are affiliated to the Fédération Suisse de Twirling-Bâton ${ }^{4}$, representing around 300 athletes. Baton twirling is often described, in terms of its technical field, by an analogy with rhythmic gymnastics (RG) while differentiating itself by the use of a single instrument - the baton - and of a greater variety of acrobatic moves.

Beyond these technical considerations, baton twirling can still be defined in terms of a dual characteristic of gender and class, which gives it a unique expressiveness. In terms of gender, and beyond the statistical evidence that only a handful of boys are involved in the sport ${ }^{5}$, baton twirling is a predominantly feminine practice open to young girls aged between approximately 5 and 20 years old. Regarding class,

$1 \quad$ This research was funded by the Swiss National Science Foundation, Division 1 (10001A_156278). Doing "Small society" through leisure activity: an ethnographic study of associative life in sport clubs based on proximity. In collaboration with Shia Manh Ly and Thomas Zannin.

2 Nearly thirty comprehensive interviews were conducted with coaches, parents, coaches, judges and club managers. The young athletes participated in collective interviews (generally in groups of three). 32 girls and one boy were interviewed for this research. The observation sessions provided the opportunity to conduct many informal interviews.

3 Clubs are mainly based in the French-speaking areas of Switzerland. Besides these, there is one club in Ticino and one in German-speaking Switzerland.

4 The Fédération Suisse de Twirling-Bâton, founded in 1972, is a member of the World Baton Twirling Federation (WBTF), the Swiss Olympic Association and the Jeunesse et Sport movement. In terms of its inclusion in federal organizations, baton twirling is represented by two "competing" international federations: the WBTF and the NBTA. The clubs which are active in Switzerland are affiliated to the FSTB, a federation recognized by Swiss Olympic since 1980. We should also mention the geographical scope of influence of the two representative bodies, more limited for the WBTF than for the NBTA.

5 There are boys involved in the practice, mostly, due to family involvement - brothers of members or sons of managers, etc. 
the activity (the historical connection with majorettes of which is well established) is rooted in models of self-presentation, body games and a stylization of appearances (clothing aesthetics, musical styles, gestures, makeup, etc.) evocative of a popular characterization - intersected, moreover, by the socio-economic profiles of female participants - and of a conventional gendered system.

Finally, the predominantly social characteristics, characterized by emotional expressiveness, support the observation of a strong feminine influence on the practice, which both values and reproduces a girls' culture (Driscoll et al. 2008) along with several associated attributes.

In terms of their structure and organization, the clubs are still defined by the fact that they are organized around a principle of generalized closeness that can be interpreted in different ways. Firstly, they are welcoming, usually far removed from the pressures and goals of elite sports. Secondly, the dominating functional, relational and economic model is maintained by close ties, primarily appealing to and involving families: supervising the athletes is a voluntary role, with the exception of the instructors, who are qualified and are paid modestly by the Jeunesse et Sport program funded by the Swiss Federal Office of Sports. Funding for the general running of the clubs comes from the sale of pastries, raffles and festive meals. Other sources of funding are the generosity and solidarity of local entrepreneurs or businesses (restaurants, carpenters, insurance companies) known to have close ties with the club leaders. Thirdly, these organizations, the number of members of which rarely exceeds twenty athletes, are structured around a powerful shared interest, giving them the appearance of a "small company" (Malatesta et al. 2014). A relationship based on inter-knowledge prevails, with young athletes and supervisors often sharing family or neighborhood ties. This tight-knit network has the characteristics of a typical sports community, marked by a kind of maternal sporting nature which is notably reflected in the central role occupied by the instructors, but also in the involvement of the older athletes in all areas of the sport. This represents a double commitment that reminds us of the central place of females in both the organization and its sustainability, but also of the discipline's attachment to the values of care and consideration for people, underpinned by an ethic of care (Gilligan 1982; Tronto 1993).

While the practice of baton twirling, in light of the above, has the characteristics of a low-profile discipline boasting little prestige or recognition, the clubs that host it nevertheless provide environments which encourage long-lasting membership and commitment (Jaccoud and Malatesta 2016), loyalty schemes and, more generally, enthusiasm. A reality which raises questions about organizational structures that promote positive, "value-laden" ways of life (Macé 2016, 11), which create bonds and protect members and, as such, embody a resource to be preserved.

It should be noted here that the relational environment that prevails in the clubs, strongly marked by familiarity and affection, has extended to welcoming and 
supervising the presence of researchers. From the outset, the ethnographic study (Cefaï 2010) has been characterized by trust and closeness (Ly and Zannin 2020). It was moreover through this familiarity that we became aware of the decision made by the Federation, which we quickly understood was perceived and feared as not only a disruption to the functioning of the clubs, but also as a threat to their very existence.

\section{Conceptual Framework}

The theoretical framework used herein consists of three theories: form of life, inquiry and care, which are articulated in order to give the best possible account of a situation of protest within the realms of commitment to an association.

Both the organization and the running of these small clubs led us to approach them as part of a form of life (Cavell 2006; Laugier 2016): a unique way of arranging relationships between people, conceptions of oneself and others, and a certain idea of collective life. It is a notion which therefore refers to the ways in which people live - through "ways of being [...], gestures and pace of life" (Macé 2016, 21). It is a reality which members value and which as such deserves some "maintenance work" (Ferrarese 2018,5 ), i.e., care, support and protection. ${ }^{6}$

In this theoretical perspective, the organized practice of a sport is not strictly defined by an overarching institution imposing rules, it is also an element of community life, both on a daily basis, but also in times of disruption and discontinuity particularly when the course of this form of life is disturbed by unexpected changes which cause disruption of both personal and collective experiences - and calls into question a specific type of commitment.

In this study, we choose to highlight a specific sequence of events, marked by the efforts of the Swiss Baton Twirling Federation, to prepare the sport for the Olympics by strengthening the selection process, making access to competitions more difficult: access being thereafter defined purely by sports performance criteria.

While we can relate the notion of a form of life to a "certain idea of living" which "one values and is supported by" (Macé 2016), it must be said that this period of events significantly perturbed the clubs. They did not expect such a decision, which was seen both as a very different way of looking at the practice of baton twirling, and as a redefinition of relationships with the athletes.

6 The news gives a certain depth to this research contribution on small clubs in which girls practice a sport. In June 2020, a scandal was widely publicized in the media, denouncing the treatment of young athletes, members of the Swiss national rhythmic gymnastics team. It was the athletes themselves who alerted the media, describing in detail the climate of abuse in which they were immersed: restrictions and eating disorders, weight monitoring several times a day, humiliations, lengthy training sessions, fatigue, etc. The goal of the two coaches, both of whom have since been dismissed, was to ensure that the national team was selected for the 2006 Olympic Games in London - which did not happen. The Head of gymnastics performance was suspended for the duration of the investigation. 
The movement the clubs initiated in response to this decision was akin to an inquiry, as defined by John Dewey. In his publication entitled The Theory of Inquiry, he describes the inquiry in terms of a process of observing, understanding and rectifying the facts, with a view to transforming - according to the now renowned term - an indeterminate situation into a determinate one (Festenstein 2008; Putnam and Putnam 2017).

This study comprises three dimensions: 1) its instrumental nature, which makes the inquiry "a method available to people to restore the continuum of their experience when it is disrupted" (Zask 2008, 2) the fact that the problems or disorders governing its implementation are "a vector of experience, because they constitute an incentive for an inquiry" (Stavo-Debauge 2012, 191), and 3) the fact that the inquiry carries with it democratic requirements as it is based on the principle of making judgements.

This is how the inquiry described here, beyond a discussion of the purposes and values of a sports activity, revealed a real attachment to a form of life and habitual actions. A form of life in which both asserting and defending it constitute tests by which ordinary individuals are led to question and challenge hierarchies, role allocations and negative rankings, on the basis of collective assumptions and requests.

Reflections evoked in relation to the continuing existence of the clubs revealed three expectations. Firstly, members expect ongoing support and a privileged and sought-after relationship between supervisors and children. Secondly, instructors, parents and the children themselves all expect that the efforts of each young athlete, regardless of the results obtained, will be recognized. And thirdly, instructors, parents and children alike all expect young baton twirlers to be able to participate in the life of the club, regardless of their ranking or aspirations.

The evidence supports adopting the care paradigm, as presented by authors such as Carol Gilligan (1982), Virginia Held (2006), Agata Zielinski (2010/2012), Sandra Laugier (2016) and Fabienne Brugère (2017), as well as authors who have broadened the scope of the meaning of care, to include a political perspective. Maintaining a worldview founded on interdependent relationships, attention to others, defending values... these are all dimensions which can be used to analyze a time of action, and to gain an insight into the objectives of the time. A paradigm which can be articulated using the notion of inquiry, and which enables us to think about what political experience can be in an otherwise apolitical context. Finally, this turbulent period has led the clubs to the conclusion that, rather than strengthening, the pressure to increase the competitive nature of baton twirling as a sport weakens them, diminishing their power and substance, at the risk of losing an understanding of the practice of collective sport, or even their disappearance altogether. 


\section{An Instruction to Prepare the Sport for the Olympics}

The investigation carried out among the clubs revealed two complementary realities. The first reality is the cohesive force of a relational system built on familiarity and "a form of attention to the human being" (Laugier 2015, 66). Being tactile, hugging, consoling, combing each other's hair or talking about school and the little things of everyday life: such is the social dimension which prevails within these communities, protecting young members and organized according to rules and intense dynamics which promote friendship and the young athletes' inclination to enjoy positive bodily experiences (Golay and al. 2011).

Moreover, some like to say that the athletes become instructors "so they don't have to leave twirling all at once".

I stay in the club because I love it. When I was abroad, it was horrible, I really missed it. I love coming here, I love coming to the hall, I love teaching the girls new things, seeing that they enjoy doing it and learning, seeing them progress and helping them to progress. I find it great. (Céline, coach, 25 years old)

The second reality: a proven commitment to mastering a specialized sports skill, punctuated with competitions, progression criteria and "transitional stages", which legitimize a disciplinary practice known to be demanding and, even more so, as a genuine sport. It is this relationship with the sports institution that club members especially value.

People say it is an "almost elitist' sport", said one organizer, smiling. "You need a certain rigor and if you want to succeed, you have to put in the effort". (Yolanda, coach and technical manager, 40 years old)

However, while these organizations unambiguously propose an activity that brings with it resources and delegates technical and physical capabilities, receiving approval of standards of sporting excellence is not the only positive outcome members seek to achieve. And particularly when these standards are at odds with the experiences and affections that are part of a community form of life (Malatesta and Jaccoud 2018).

Of course, we try to maintain the girl' level and get them to progress further. But the objectives... We mostly talk about them among ourselves at the beginning of the season, and then we see how things go. We don't talk about them with the girls. At the end of the day, talking about objectives is a way of creating cohesion among monitors while also making sure the girls live their lives. (Marianna, coach, 30 years old)

We can therefore see that it is rare to speak only of performance and technicality, especially when the girls' efforts are evoked. 
Look at the girls. Of course, sometimes they drop the baton, it happens, but they are so cute, you can see that they are enjoying themselves. (Carina, coach, 20 years old)

Similarly, the idea of training is most often associated with the "real" abilities of the athletes. French and Italian choreographers are sometimes hired for one-off projects, but their presence is rarely lasting, as their methods are generally not in sync with the relationships established between the instructors and children.

He will be stricter, correct them, seek to perfect their moves. We have to go over all the basics, everything the girls have done. (Yolanda, coach and technical manager, 40 years old)

Instructors may then adapt these choreographies to the girls' abilities and preferences in preparation for upcoming competitions.

But while the coaches are careful, so too is the audience. A number of observation sessions have thus shown that while the stands applaud the best performing athletes, they also know how to recognize and praise the courage of those less skillful, regularly heard saying that "they have the right to participate too".

The sports activities presented in these clubs, combining formal learning and emotional relationships, have been called into question since the Federation embarked on a process of preparing baton twirling for the Olympics. This can be described as a desire to structure the organization of competitions in a more selective way, with the aim of raising the athletes' level, so that they will achieve higher rankings in international competitions. This change is reflected in several measures undertaken. Firstly, the creation of a national tier, with extra specific training for the best athletes in the clubs. Secondly, the introduction of an additional technical examination qualifying access to the Swiss championship; the only official competition, organized in three rounds, which opens access to international championships; and technical exams for the three different categories of athletes (beginners, juniors and seniors). In this new system, these exams take place without an audience, and without the presence of monitors. The girls are thus in front of the judges. The adoption of a charter formalizing the obligations of the clubs, their leaders and athletes was added to this symbolically, which cites Olympic moral principles.

Indeed, it was quickly observed that the rigors of the institution were likely to generate exclusions, due to the competitive process of sorting and selecting athletes. This menacing grip of technical requirements cast a shadow over the tradition of openness in clubs, which had always insisted that the practice should also be fun. 


\section{The Inquiry: From an Indeterminate to a Determinate Situation}

In the philosophical tradition of pragmatism, the theory of inquiry, developed by John Dewey, with which the philosopher sought to understand the capacity of individuals not only to adapt to changing environments but also to cope with them, operates on two levels. The first level is the perturbing experience associated with problematic situations which lead to disruptions in the links between an individual, or a group, and their environments. Secondly, in terms of reconstructing the experience, or re-establishing a disrupted continuity, which involves identifying the problem encountered, defining it and finding solutions to restore the necessary balance (Zask, 2008).

Identifying a bad experience, as well as the efforts made to regain a positive experience in a context of openness and benevolence, focuses particularly on the problem of access to competition, and therefore the opportunity for each person to show the results of the work and efforts made throughout the year at the same time as others.

The below extract presents a factual outline of this indeterminate situation and the solutions envisaged to reconstruct a new continuity.

Two years ago, when I saw the downward spiral they risked falling into, I wrote a letter saying that I didn't understand what they were doing. If we get rid of the masses, we will no longer have a pyramid that stands the test of time. And they do everything to promote the top of the pyramid. So, in one of the competitions, I asked for all technical requirements to be removed. So that a girl who was... less skilled, shall we say, could still enjoy performing a solo. (Sylvie, coach and technical manager, 45 years old)

In this quote, we can see aspects of the movement to protect transmission of the art of baton twirling: i. e., a lack of understanding of a decision which affected the very functioning of the clubs through a selection process regulated by the institution alone, and through a hierarchy of training sessions and venues.

The analysis undertaken by the clubs, managers, instructors and children focused on two changes: the creation of a national framework and the Federation's control of admission to the various championships around which the practice is organized.

\subsection{National Organization}

The development of a national framework to optimize sports performance was relatively rapid. Instructors were called upon to provide training and clubs were asked to send athletes who met the technical mastery criteria. However, although 
it was not outright rejected members did not receive this discipline as part of the expected progress of baton twirling.

Being in this environment is demanding. One weekend per month, you have to travel. There are some people with the school who are a bit anxious. And you need a coach who is willing to travel. I know I can't. But we say to them that if they want to go, we will manage to find someone to accompany them. "We'll always make sure that you have someone with you". If they can go, that's great. If you can experience an international competition at least once, it's a wonderful opportunity. (Julia, coach, 32 years old)

The criticism focuses on two aspects in particular. Firstly, on the material conditions of participation: although usually only general events require travel, being part of the national tier entails regular trips for training in addition to the usual training trips for the respective clubs. This requirement of athletes' and instructors' time is not self-evident and is worthy of debate. Secondly, on the discrepancy between this new offer and the real expectations of athletes, most of whom do not wish to go on to join an international or even a national elite. Indeed, this extra commitment to the sport is seen as "just one of many things", with school often remaining a priority, along with friends and family time. In other words, it is not a question of challenging a member's attachment to the club and baton twirling, but rather of challenging a commitment solely defined by the "sporting dimension" of it.

The national tier is also viewed as a means to separate athletes by the distinction that seems to be made between members of the national tier and the other members.

Before, you had to be one of the top 3 or 4 . Then afterwards, if you wanted to, you could go (to participate in an international competition). However now, it is still the top 3 or 4 , but the selection is sometimes unfair, especially among seniors (from the age of 14 onwards) and I'm not the only one who thinks so. Those selected are all part of the network. (Céline, coach, 25 years old)

In conclusion, although the national tier may meet the requirements to improve the technical performance of some athletes (certainly a minority), for most others it is more likely to undermine the smooth-running world in which familiar things families, judges, audiences, halls, places and people - are the backdrop of their sport.

\subsection{Competitions}

Unsurprisingly, the competition agenda punctuates the seasons and training sessions, for each club and each baton twirler, whether you are participating in the competitions or not, and whether the club will be represented or not. These encounters, which are as much opportunities to confront each other in competition as to meet, are therefore important rituals which bring the whole community of baton twirlers together, as well as their families. 
The modification of the rules of access to the Swiss championship, which are now more restrictive, has essentially had two consequences. The first consequence is that only a minority of athletes are now eligible to be fully-fledged competitors. The second consequence is that, in an environment which places value on motor skills and abilities that are subject to the requirements of a performance-oriented culture, girls are now generally judged solely on heteronomous criteria, reflecting training practices and learning objectives set by the sports institution.

Today, none of the little girls want to enter competitions (smiles). (Céline, coach, 25 years old)

The interviews reflect a preoccupation with these pressures to conform to a physical standard. In this respect, the composition of the teams (group choreography of 6 athletes), shows that the instructors also try to fulfil the girls' expectations. The choreographic and technical composition is determined by the abilities of those wishing to join the group. This is in contrast with an alternative method, which consists of choosing the girls by individually assessing what they are capable of doing. The ethnographic study of clubs reveals how, most of the time, this second procedure is only observed when a person from outside the club (as we have seen, always a man) a commissioned choreographer, decides unilaterally to do so according to technical and sometimes aesthetic criteria. In practice, this method never lasts long. The parents get angry and the girls get upset. We can add, for the purpose of understanding how to best prepare for the competition, that the girls involved in the club often know each other prior to becoming members, from their neighborhood, school, or even coming from the same family. The links between them are significant factors in their choice to participate in these training sessions.

In other words, while the national competition is perceived to be both difficult to access and highly selective, participation in other events (a Cup and a Criterium) is increasingly sought after. In these events, participants not selected for the Swiss championships are included, such as juniors whose technical examinations were deemed to be inadequate, as well as athletes among the elite, who take part in order to prepare for the next competitions. These events ensure that each person finds their place and ultimately make it possible to organize an activity that is appreciated less for its sport than for its continuity of a form of life in which there is no shame in making mistakes or being clumsy. Comparing oneself to others is part and parcel of the nature of competition but does not diminish the pleasure of being part of these events. 


\section{Fighting for What Matters: Care and the Political Dimension}

While the Federation saw in this new direction an opportunity to develop the sport of baton twirling and bring it closer to Olympic sports, the ethnographic fieldwork shows how the clubs saw it as something else: a real threat to their existence. Two types of criticism have been developed in detail. The first addresses the demands and claims to supremacy made by the sporting institution which sorts and selects those who will be included and excluded from sports recognition, in accordance with their criteria for performance.

It takes years to master the technical movements and thus pass the routines and degrees (technical exams) to be able to participate in the championships. So, the little girls are too young to learn the technical movements. It takes time, we need to give them more time. Furthermore, they are at an age where they are becoming conscious of their bodies, so we should not impose models. (Marianna, coach, 30 years old)

The second criticism exposes the fragility of small organizations, dedicated to learning and promoting a scarcely known sport. Despite its consensual practice and art of doing things in a way which is open to a variety of talents and skills, it is still threatened by the increasingly demanding technical requirements. And this poses the risk of losing children, for whom this activity is nevertheless a source of learning and enjoyment.

I was told that I didn't know what I was talking about... But by asking for this open category, which was accessible to all, they changed the rules for the Haldi Cup. Before, this Cup was reserved for competitors up to the age of 12 years old. So, it was for young girls. And then, given that there are a lot of juniors who can't participate in the Swiss championships, they reopened this competition for the junior age group, and in this competition, there are no degree or routine requirements (unlike technical exams). All the girls can do a freestyle performance (solo presentations), whatever be their level. All girls aged between 12 and 17 years old can do a junior freestyle performance, or whatever they like. And there were more entries for this than for any other competition, as it was open to everyone. And this, despite the fact that it didn't give access to places competing in the championships. (Sylvie, coach and technical manager, 45 years old)

The importance of maintaining the form of life which takes shape in the clubs is also found in the inherent need to not leave any places empty, literally to fill the gaps, in their organization.

Baton twirling is something I've always loved, but for my parents, it wasn't like now where parents follow their kids, so I only attended two or three 
practices. My daughter decided she wanted to do it too, so I followed her wishes. I was asked if I wanted to be a monitor for the youngest kids. I said yes ok. Then after that, I spent time on leotards, finding new models, etc.... And then, one day, the technical manager left, and I was asked "Would you like to come back and do the job again?". I was a bit stressed, I didn't know what to do. Two of us ended up sharing the position and then the other person fell pregnant and I found myself doing the job alone: that's how I started out (smiles). (Yolanda, coach and technical manager, 40 years old)

"Trying to find solutions to everything" is somewhat the motto of every club, especially when it comes to turning such a diverse group of athletes into a membership community. This motto, cited in an interview, clearly highlights both the desire to maintain established ways of doing things, including when they are out of sync with the requirements of the sports institution, as well as the development of adjustments or adaptations to maintain an inclusive and participatory form of sports life, which members value and which values them.

A significant concern is to protect young athletes engaged in learning a sport from the severities of the competitive sports environment, "we try to achieve the objectives together, to ensure that they all succeed their routines (a technical exam), for example", but also the vigilance used to protect the benevolent relationships between instructors and young athletes clearly guides the analysis towards an ethic of care, expressing sensitivity to caring for others, as well as benevolence (Brugère 2009) or respect for the uniqueness of individuals and for fair institutions (Fisher and Tronto 1990; Zielinski 2010/2012).

Moreover, the critical actions resulting from the investigation process are rooted in care. In light of the importance given to satisfying strictly human needs, they explore the links that may exist between these two spheres: the club and the wider sports institution. On the one hand, a world of trust, characterized by mutual agreements based on warmth and shared values. On the other hand, a world requiring a certain physical condition, imposed by the categories established by the sports institution. By referring here to the perspectives and issues raised within an ethic of care, it can be argued that the positions and requests for development made by the clubs can then be recognized as being inextricably moral and political. As we can see in this ethnographic field study, defending a form of life is moral when it creates an environment in which vulnerability, rather than being erased, can be based on the premise of social bonds. It is also moral when it gives substance to a sports system in which one can love the children, support other people's children as well, and defend their simple right to enjoy a sport, even if it is one which is somewhat underestimated.

Finally, defending a form of life built on an ethic of care is political as well as a political experience when it leads ordinary people to concretely commit themselves to actions undertaken to preserve a connection and to question the world, to say what 
is wrong and what impedes the flow of life. This can occur through the articulation of rules for the common good and general interest which are not based on abstract and disembodied principles, but rather on a concern to ensure the continuity of a lasting and familiar shared framework of a way of life.

\section{Conclusion}

In the theory of collective action, as proposed by John Dewey, individuals who are affected by the effects of an indeterminate situation set in motion a twofold process of experimentation and knowledge in order to change that indeterminate situation into something more coherent. This process, an inquiry, is inseparably moral and political insofar as it is based on a statement of values and reveals ways in which society is organized.

We observed the deployment of this kind of inquiry in these small sports clubs. Clubs which, when faced with a heavy-handed instruction to prepare a hitherto relatively uncompetitive sport for the Olympics, voiced their wish to continue exercising their sport in their way, which is infused with a principle of benevolence.

The ethnographic study of this particular aspect of club life has enabled us to highlight several aspects. On the one hand, the fact that a sports life - which is enjoyed because it promotes a certain way of conceiving a community in its uniqueness, vulnerabilities, and skills - can be undermined by an institution whose proposals are inspired by an ethos of control, discipline, and excelling oneself. On the other hand, how such a clash enables us to gain an insight into the development of a critical relationship with an overarching institution.

The demands and requests for adjustments submitted by the clubs have thus revealed the nature of an institution in which the conditions for individual selffulfillment and the production of content expressing individuality are not met. In detail, the inquiry conducted by the clubs highlighted three major obstacles to this outcome: 1) the principle of strict performance, which, by ranking excellence in a hierarchy, is at odds with developing self-esteem; 2) the imposition of strict physical standards which subject athletes to a regime of assessment based on the scrutiny of a third party, and 3) finally, the suppression of singular identities, in favor of a sports identity formatted by the requirements of the institution.

In all cases, the challenges raised have highlighted the centrality of care, or the attention to be paid to the care and protection of the host organizations and the people they receive, with a view to maintaining relationships marked by concern for others and attentiveness to their needs. On this point, the instructors and coaches made it clear that they were not supervising soulless athletes, shaped by technical know-how and by the demands of self-correction, but rather fragile and vulnerable children, whose paths are influenced by the different social spheres in which they 
live. It was also pointed out that no demands can be imposed on them which may be detrimental to their development or which diminish their pleasure in participating in the sport. Such empirical observations therefore demonstrate the epistemological interest of combining care and inquiry approaches.

It can also be said that a meticulous ethnographic study of the associative community contributes towards the development of a reflection articulating the nature of commitment in an association, collective action, and the development of a critical perspective. Thus, even a modest sports club, if it is part of a structure organized according to norms and requirements similar to those of an already existing club, is also part of an intersubjective form of life, built and fiercely defended by its members. It is this defense which brings institutions and situations into contact and engenders an inquiry. This confrontation is then able to produce a reflection on society, on the way in which it is organized, and on the prevailing balance of power therein. Thus, belonging to a sports leisure club can be the cornerstone of experience of learning and developing a worldview, providing the opportunity to think about limits, challenges, expectations and boundaries. As such, it participates in the construction of a political and, ultimately, democratic experiment.

\section{References}

Auyero, Javier, and Lauren Joseph. 2007. Introduction: Politics Under the Ethnographic Microscope. Pp. 1-13 in New Perspectives in Political Ethnography, edited by Lauren Joseph, Matthiew Mahler, and Javier Auyero. Berlin: Springer.

Brugère, Fabienne. 2009. Pour une théorie générale du care. La Vie des Idées. May 82009.

Brugère, Fabienne. 2017. L'Ethique du "Care". Paris: PUF.

Cavell, Stanley. 2006. Forward. Pp. xiii-xiv in Life and Words. Violence and the Descent into the Ordinary, edited by Veena Das. Berkley: University of California Press.

Cefaï, Daniel (ed.). 2010. L'engagement ethnographique. Paris: Editions de l'EHESS.

Driscoll, Anne K., Russell, Stephen T., and Lisa J. Crockett. 2008. Parenting Styles and Youth Well-Being Across Immigrant Generations. Journal of Family Issues 29(2): 185-209.

Ferrarese, Estelle. 2018. La critique comme forme de vie démocratique. Multitudes 71(2): 189-198.

Festenstein, Matthew. 2008. John Dewey: Inquiry, Ethics and Democracy. Pp. 87-109 in The Oxford Handbook Of American Philosophy, edited by Cheryl Misak. Oxford: Oxford University Press.

Fisher Bereni, and Joan Tronto. 1990. Towards a Feminist Theory of Caring”. Pp. 36-54 in Circles of Care, edited by Emily Abel, and Margaret Nelson. Albany, SUNY Press.

Fraser, Nancy. 1990. Rethinking the Public Sphere: A Contribution to the Critique of Actually Existing Democracy. Social Text 25/26: 56-80.

Gilligan, Carol. 1982. In a Different Voice: Psychological Theory and Women's Development. Cambridge Massachussets and London England: Harvard University Press.

Golay, Dominique, Malatesta, Dominique, Perrin Céline, and Christophe Jaccoud. 2011. Faire du sport pour acquérir une image positive de soi? L'analyse de l'engagement des filles dans le twirling bâton suivant la théorie de l'objectification. Pp. 53-68 in Sportives dans leur genre? Permanences 
et variations des constructions genrées dans les engagements corporels et sportifs des femmes, edited by Monica Aceti, and Christophe Jaccoud. Bern: Peter Lang.

Held, Virginia. 2006. The Ethics of Care: Personal, Political, and Global (second ed.). Oxford New York: Harvard University Press.

Jaccoud, Christophe, and Dominique Malatesta. 2016. "Quand s'engager vaut le coup: des filles dans des clubs de twirling bâton et de football». Pp. 23-35 in L'engagement sportif au prisme des sciences sociales, edited by Jean-Paul Callède and Gilles Ferréol. Louvain-la-Neuve: Editions EME.

Laugier, Sandra. 2016. Politics of Vulnerability and Responsibility for Ordinary Others. Critical Horizons. A Journal of Philosophy and Social Theory 17(2): 207-223.

Ly, Shia Manh, and Thomas Zannin. 2020. «Tu fais partie de l'équipe!» L'ethnographie dans les relations amicales. Les politiques sociales $1 \& 2: 31-42$.

Macé, Marielle. 2016. Styles. Critique de nos formes de vie. Paris: Gallimard.

Malatesta, Dominique, Golay, Dominique, and Christophe Jaccoud. 2014. Circulation des savoirs, construction d'appartenances et affirmation de soi. Les filles dans des clubs de football et de twirling bâton : entre logique sportive et logique sociale. Pp. 141-157 in Transmission des savoirs: loisir et culture, edited by Olivier Thevenin and Pascale Marcotte. Paris: L'Harmattan.

Malatesta, Dominique, and Christophe Jaccoud. 2018. Des enfants dans des activités de loisir organisé. Expérience politique et de citoyenneté. Pp. 167-180 in Citoyenneté et éducation par la société, edited by Guy Labarre. Besançon : PUFC.

Putnam, Hilary, and Ruth Anna Putnam. 2017. Pragmatism as a Way of Life: The Lasting Legacy of William James and John Dewey. Cambridge: Harvard University Press.

Tronto, Joan. 1993. Moral Boudaries: A Political Argument for an Ethic of Care. New York: Routledge.

Stavo-Debauge, Joan. 2012. Des «événements» difficiles à encaisser. Un pragmatisme pessimiste. Pp. 191-224 in L'expérience des problèmes publics, edited by Daniel Cefaï, and Cedric Terzi. Paris: Editions de l'EHE.

Zask, Joelle. 2008. Le public chez Dewey. Une union sociale plurielle. Tracés 8(15) : 169-189.

Zielinski, Agata. 2010/2012. L'éthique du care. Une nouvelle façon de prendre soin. Etudes 413(12): 613-641. 
Varia 


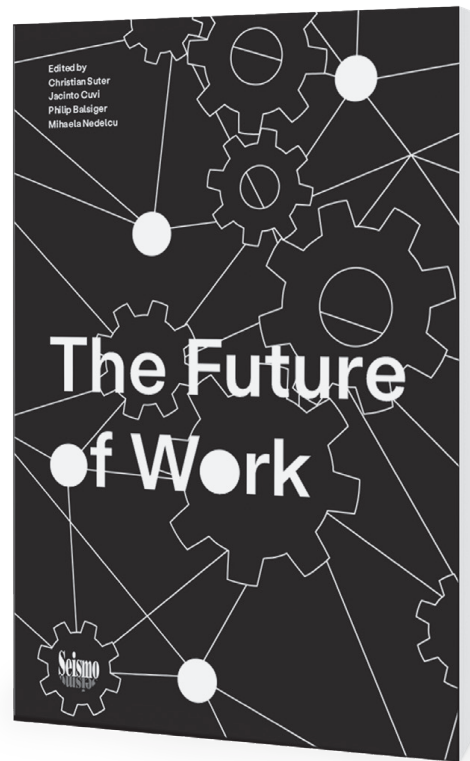

Christian Suter, Jacinto Cuvi, Philip Balsiger, Mihaela Nedelcu (ed.)

\section{The Future} of Work

ISBN 978-3-03777-244-7 376 pages, $15.5 \times 22.5 \mathrm{~cm}$ Fr. 42.- / Euro 38.-

\section{Simg}

Seismo Press Social sciences and social issues

The Future of Work is a collective, interdisciplinary effort to grasp the trends that were reshaping the world of work before the Covid-19 pandemic along with its effects on the workers and labour markets. Written in the immediate aftermath of the outbreak, as countries around the world grappled with the economic fallout, the volume's twelve contributions from leading researchers and junior scholars draw on the rich debates of the 2019 congress of the Swiss Sociological Association on the future of work held at the University of Neuchâtel in the fall of 2019. The chapters, divided into five sections, cover issues ranging from the impacts of digital technologies and globalization to the experience of marginalized workers and the future of academia. Their critical insights into the historical dynamics and lived experiences behind the transformation of work provide a framework to understand the fate of workers and occupations in these unsettling times.

Christian Suter is professor of sociology at the University of Neuchâtel, Switzerland. His research has focused on social and economic inequalities, social indicators and quality of life, as well as on globalization and world society. Jacinto Cuvi is visiting fellow at the London School of Economics. He holds a PhD in sociology from the University of Texas at Austin. His research focuses on informal labour in the urban South. Philip Balsiger is an assistant professor of economic sociology at the University of Neuchâtel, Switzerland. In his work he is interested in sociological approaches to markets, with a particular attention on contentious processes. Mihaela Nedelcu is titular professor at the Institute of Sociology and project leader in the nccr-on the move at the University of Neuchâtel, Switzerland. Her research analyses the social impact of digital technologies and the transnationalization of social life, with a focus on e-diasporas, e-borders, and transnational ageing. 